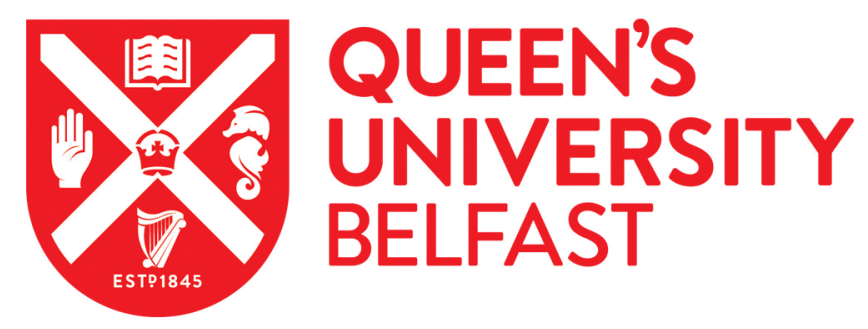

\title{
The CTLA4 + 49AVG and CT60 polymorphisms and chronic inflammatory arthropathies in Northern Ireland
}

\author{
Suppiah, V., O'Doherty, C., Heggarty, S., Patterson, C., Rooney, M., \& Vandenbroeck, K. (2006). The CTLA4 + \\ 49A/G and CT60 polymorphisms and chronic inflammatory arthropathies in Northern Ireland. Experimental and \\ Molecular Pathology, 80(2), 141-146. https://doi.org/10.1016/j.yexmp.2005.09.004
}

Published in:

Experimental and Molecular Pathology

Queen's University Belfast - Research Portal:

Link to publication record in Queen's University Belfast Research Portal

\section{General rights}

Copyright for the publications made accessible via the Queen's University Belfast Research Portal is retained by the author(s) and / or other copyright owners and it is a condition of accessing these publications that users recognise and abide by the legal requirements associated with these rights.

Take down policy

The Research Portal is Queen's institutional repository that provides access to Queen's research output. Every effort has been made to ensure that content in the Research Portal does not infringe any person's rights, or applicable UK laws. If you discover content in the Research Portal that you believe breaches copyright or violates any law, please contact openaccess@qub.ac.uk. 


\title{
The CTLA4 + 49A/G and CT60 polymorphisms and chronic inflammatory arthropathies in Northern Ireland
}

\author{
V. Suppiah ${ }^{\text {a }}$, C. O’Doherty ${ }^{\text {a }}$, S. Heggarty ${ }^{\text {a }}$, C.C. Patterson ${ }^{\text {b }}$, M. Rooney ${ }^{\mathrm{c}}$, K. Vandenbroeck ${ }^{\mathrm{a}, *}$ \\ a Applied Genomics Research Group, School of Pharmacy, McClay Research Centre, The Queen's University of Belfast, \\ Belfast BT9 7BL, Northern Ireland, UK \\ ${ }^{\mathrm{b}}$ Department of Epidemiology and Public Health, The Queen's University of Belfast, Northern Ireland, UK \\ ' Department of Rheumatology, The Queen's University of Belfast, Musgrave Park Hospital, Belfast, Northern Ireland, UK
}

Received 22 August 2005

Available online 24 October 2005

\begin{abstract}
Rheumatoid and juvenile idiopathic arthritis (RA, JIA) are chronic inflammatory arthropathies with an autoimmune background. The cytotoxic T-lymphocyte antigen-4 (CTLA-4) protein plays a key role in the down-regulation of T cell activation.

We analyzed the CTLA4 $+49 \mathrm{~A} / \mathrm{G}$ and CT60 polymorphisms in cohorts of Northern Irish RA and JIA patients and healthy control subjects using restriction fragment length polymorphism methods.

The +49 A allele was increased in RA $(61.2 \% ; P=0.02 ; \mathrm{OR}=1.28 ; 95 \%$ C.I. $=1.04-1.58)$ and JIA $(61.8 \% ; P=0.14)$ patients compared to the control population (55.3\%). No significant association was observed for the CT60 polymorphism. Haplotype analysis revealed a significantly different distribution of $+49 \mathrm{~A} / \mathrm{G}-\mathrm{CT} 60$ haplotypes in RA and JIA patients compared to controls ( $P$ value $<0.00001$ and 0.030 for comparison of RA and JIA patients with controls, respectively).

Our results suggest that the CTLA-4 gene is involved in predisposition to inflammatory arthropathies in the Northern Irish population. (C) 2005 Elsevier Inc. All rights reserved.
\end{abstract}

Keywords: CTLA-4; +49 A/G; CT60; Rheumatoid arthritis; Juvenile idiopathic arthritis; Susceptibility

\section{Introduction}

Chronic inflammatory arthropathies such as adult rheumatoid arthritis (RA) and the juvenile form-juvenile idiopathic arthritis (JIA)-are believed to be multifactorial diseases characterized by activation and synovial infiltration of immune cells such as macrophages and lymphocytes that are aimed primarily at the joints (Feldmann et al., 1996). Even though these autoimmune conditions share many similarities, RA and JIA are distinctly different from one another (Grom et al., 1994). The prevalence of RA in Ireland has been estimated to be 5/1000 (Power et al., 1999). The major hallmark of RA consists of chronic symmetrical joint inflammation with typical autoimmune features, while JIA is a collection of childhood inflammatory arthropathies all having arthritis as a common determinant. Patients with 4 or less joints affected are classified

\footnotetext{
* Corresponding author. Fax: +44 2890247794.

E-mail address: k.vandenbroeck@qub.ac.uk (K. Vandenbroeck).
}

as having pauciarticular disease while patients with more than 5 affected joints are classified as having polyarticular disease.

Evidence suggests that both RA and JIA are influenced by both multiple genetic and yet-to-be identified environmental factors. The sibling risk ratio for a full sibling of a patient is estimated to be 15 for JIA (Glass and Giannini, 1999) and 8 for RA (Risch, 1987). Familial aggregation of clinical features supports a genetic background in both RA and JIA (Moroldo et al., 2004). Several genome-wide scans have consistently associated the HLA region to both diseases in many populations (Osorio Y Fortea et al., 2004; Eyre et al., 2004; Thompson et al., 2004; Jawaheer et al., 2001). However, genes in the HLA region are thought to account for not more than a fraction of the overall genetic component of these diseases, with multiple genes outside the HLA region contributing towards disease susceptibility in an additive manner (Ollier, 2004; Gregersen, 2003).

It is known that $\mathrm{T}$ cells require two signals to be fully activated. The first signal is antigen-specific and arises from recognition of antigen bound to a major histocompatibility 
complex (MHC) molecule by the T cell receptor. The second is a co-stimulatory signal driven by interaction between a molecule, either CD80 or CD86 on the antigen presenting cell, with CD28 on the T cells. This co-stimulation signal can be inhibited by CTLA- 4 which is also expressed on the surface of the T cells. This CTLA-4-ligand interaction contributes to maintaining tolerance to self-antigens by acting as a negative regulator of this second co-stimulatory signal as well as an inducer of clonal anergy (Oosterwegel et al., 1999). CTLA-4 knockout animal models are known to develop severe autoimmune diseases (Waterhouse et al., 1995; Tivol et al., 1995).

The CTLA- 4 gene consists of 4 exons and has been mapped to chromosome 2q33.3 (Dariavach et al., 1988). The four most frequently studied polymorphisms are a dinucleotide repeat in the $3^{\prime}$ untranslated region, an $\mathrm{A} / \mathrm{G}$ transition in exon 1 at position +49 , a $\mathrm{C} / \mathrm{T}$ transition in the -318 position of the promoter sequence and more recently a $\mathrm{C} / \mathrm{T}$ transition within the $3^{\prime}$-untranslated region (Ueda et al., 2003). The $+49 \mathrm{~A} / \mathrm{G}$ SNP leads to a transition from alanine to threonine amino acid substitution. It is the G allele of this SNP that has been found to be associated with predisposition to many autoimmune diseases. The CT60 A allele has been shown to be protective while the $G$ allele increases susceptibility to several autoimmune diseases (Ueda et al., 2003). The authors of the latter study also found the G allele of this SNP to be associated with lower mRNA levels of soluble CTLA-4 isoform, thus providing a rationale for a functional role in susceptibility to autoimmune diseases.
Table 1 summarizes all the studies that have been done to date investigating the effects of CTLA-4 gene in RA (Cai et al., 2005; Lee et al., 2003; Rodríguez et al., 2002; Vaidya et al., 2002; Hadj Kacem et al., 2001; Yanagawa et al., 2000; Matsushita et al., 1999; Gonzalez-Escribano et al., 1999; Seidl et al., 1998; Orozco et al., 2004; Lee et al., 2002; Barton et al., 2000; Milicic et al., 2001). Results have been conflicting with some studies hinting towards association with RA, while others claiming to find no association at all. So far, only one study has been done on JIA patients (Forre et al., 1997) where the authors found an association of the $+49 * \mathrm{G}$ allele with early onset pauciarticular juvenile chronic arthritis with chronic iridocyclitis. In view of this ambiguity, we decided to investigate the effect of 2 single nucleotide polymorphisms (SNPs), the +49 $\mathrm{A} / \mathrm{G}$ and CT60, in the CTLA-4 gene in susceptibility to RA and JIA patients in a population that has not yet been investigated before; i.e. a Northern Irish population. In this study, we specifically investigated the single- and two-marker haplotype association of the $+49 \mathrm{~A} / \mathrm{G}$ and CT60 SNPs.

\section{Subjects and methods}

\section{Subjects}

A total of 342 patients ( 289 with clinically definite RA and 72 with clinically definite JIA according to the ARA and ILAR criteria (Arnett et al, 1988; Petty et al., 1998)) and 2 sets of controls were used in this study. All patients and controls were of Northern Irish descent. Patients were recruited from the Musgrave Park Hospital and Belfast City Hospital, Northern Ireland. The first group of controls consisted of 168 unrelated healthy blood donors

Table 1

Published association studies on CTLA-4 in RA

\begin{tabular}{|c|c|c|c|c|}
\hline Association & Ethnicity & Study size & Polymorphism(s) studied & Major findings \\
\hline \multicolumn{5}{|l|}{ Positive } \\
\hline Cai et al. (2005) & China & 326 RA vs. $250 \mathrm{C}$ & +49 A/G CT60 & $\begin{array}{l}+49 * \mathrm{G} \text { allele and } \mathrm{CT} 60 * \mathrm{G} \text { allele associated with RA } \\
(P=0.028 \text { and } P=0.007, \text { respectively). } \\
\text { Haplotypes }+49 * \mathrm{G}-\mathrm{CT} 60 * \mathrm{G} \text { and }+49 * \mathrm{~A}-\mathrm{CT} 60 * \mathrm{G} \\
\text { were associated with disease }(P=0.0015 \text { and } P=0.0425 \text {, respectively). }\end{array}$ \\
\hline Lee et al. (2003) & Taiwan & 186 RA vs. 203 C & $+49 \mathrm{~A} / \mathrm{G}$ & $+49 \mathrm{G} / \mathrm{G}$ genotype associated with RA $(P=0.008)$ \\
\hline Rodríguez et al. (2002) & Spain & 141 RA vs. $194 \mathrm{C}$ & $(\mathrm{AT})_{\mathrm{n}}$ & Linkage for $(\mathrm{AT})_{\mathrm{n}}$ with RA $(P=0.02)$ \\
\hline Hadj Kacem et al. (2001) & Tunisia & 60 RA vs. $150 \mathrm{C}$ & $+49 \mathrm{~A} / \mathrm{G}(\mathrm{AT})_{\mathrm{n}}$ & $\begin{array}{l}\text { No association of the }+49 \mathrm{~A} / \mathrm{G} \text { SNP with RA; } \\
\text { linkage for }(\mathrm{AT})_{\mathrm{n}} \text { with } \mathrm{RA}(P=0.001)\end{array}$ \\
\hline Yanagawa et al. (2000) & Japan & 85 RA vs. $200 \mathrm{C}$ & $+49 \mathrm{~A} / \mathrm{G}$ & $\begin{array}{l}+49 * \mathrm{G} \text { allele associated with RA }(O R=2.53, C I=1.74-3.32) \\
\text { association enhanced with HLA-DRB } 1 * 0405 \text { status. }\end{array}$ \\
\hline Matsushita et al. (1999) & Japan & 461 RA vs. $150 \mathrm{C}$ & $+49 \mathrm{~A} / \mathrm{G}$ & $\begin{array}{l}+49 * \mathrm{G} \text { allele associated with HLA-DRB } 1 * 0405 \\
\text { patients vs. controls }(P=0.014)\end{array}$ \\
\hline
\end{tabular}

Negative

Orozco et al. (2004)

Lee et al. (2002)

Barton et al. (2000)

Milicic et al. (2001)

$\begin{array}{lll}\text { Spain } & \text { 433 RA vs. 398 C } & \text { CT60 } \\ \text { Korea } & \text { 86 RA vs. 86 C } & \begin{array}{l}-318 \mathrm{C} / \mathrm{T} \\ \end{array} \\ & & +49 \mathrm{~A} / \mathrm{G} \\ \text { UK } & \text { 192 RA vs. 96 C } & +49 \mathrm{~A} / \mathrm{G} \\ \text { Spain } & \text { 136 RA vs. 144 C } & \\ \text { UK } & \text { 421 RA vs. 452 C } & +49 \mathrm{~A} / \mathrm{G}\end{array}$

No association irrespective of HLA-shared epitope status. No association.

No association irrespective of HLA-DRB $1 * 04$ allele.

No association irrespective of shared epitope.

Abbreviations used: $\mathrm{RA}=$ rheumatoid arthritis, $\mathrm{C}=$ healthy controls . 
while the second set of controls included 307 unrelated healthy children aged 12 to 15 who were selected from a random sample of Northern Ireland schools (McCormack et al., 2001). All patients were assessed by a rheumatologist and fulfilled the American College of Rheumatology criteria for RA (Arnett et al., 1988; Petty et al., 1998; Wood, 1978). Patients were included in the study after giving written informed consent. In the case of the JIA patients, written informed consent was obtained from their legal next-of-kin. This study was approved by the Research Ethics Committee of Queen's University Belfast.

\section{Genotyping}

Genotypes of the $+49 \mathrm{~A} / \mathrm{G}$ and $\mathrm{CT} 60$ polymorphisms were determined by PCR-restriction fragment length polymorphisms (PCR-RFLP) as described elsewhere (Suppiah et al., 2005).

\section{Statistical analysis}

Chi-squared analysis of genotype, allele and carrier counts was performed for RA patients, JIA patients and healthy controls, as well as for comparison of all patients against controls by means of the SPSS statistical package (SPSS, Chicago, IL, USA). Haplotype frequencies for the RA and JIA patients and controls were obtained with Arlequin while comparison of haplotypes was performed using the EHPlus program (Zhao and Sham, 2002) and $P$ values are based on 10,000 permutations. Each SNP was tested for deviation from Hardy-Weinberg equilibrium using the Arlequin program version 2.0, which was also used to test for evidence of linkage disequilibrium between the two polymorphisms. Power calculation was performed at (http://www.calculators. stat.ucla.edu/). Probability $(P)$ values less than or equal to 0.05 were considered to be statistically significant.

\section{Results}

The $+49 \mathrm{~A} / \mathrm{G}$ polymorphism in the CTLA-4 gene was in first instance genotyped in the full sample of 289 RA and 72 JIA patients, and in the healthy controls of Group 1 (Table 3). Initial comparison showed an increased frequency of the +49 $\mathrm{A} / \mathrm{G}^{*} \mathrm{~A}$ allele in the RA group (data not shown). As the majority of studies reporting disease association with this SNP hint towards increased frequency of the G allele (Cai et al., 2005; Lee et al., 2003; Vaidya et al., 2002; Yanagawa et al., 2000; Matsushita et al., 1999; Gonzalez-Escribano et al., 1999; Seidl et al., 1998), we wondered whether the association seen in our study could be due to any idiosyncratic characteristics specific to this control population (168 healthy blood donors). Therefore, $+49 \mathrm{~A} / \mathrm{G}$ distribution in a second, distinctive Northern Irish control population consisting of 307 Northern Irish 12 to 15-year-old school children was compared to that in Group 1. As shown in Table 2, allele, phenotype and genotype frequencies did not differ between Group 1 and Group 2. Neither of both control populations deviated from HardyWeinberg equilibrium for this SNP $(P>0.05)$. Further comparisons were done with the combined control group of 475 individuals.

Table 3 shows the results of the analysis for the $+49 \mathrm{~A} / \mathrm{G}$ SNP in the RA and JIA patient samples. Both individual phenotypes (rheumatoid arthritis and juvenile idiopathic arthritis) as well as the common phenotype (inflammatory arthropathies) were analyzed for association with variants in CTLA-4. The allele frequency of the A allele was significantly increased in RA patients (61.2 vs. $55.3 \%$ in controls; $P=$ $0.022, \mathrm{OR}=1.28,95 \% \mathrm{CI}=1.04-1.58)$ and in the total
Table 2

Allele, phenotype and genotype frequencies of the $+49 \mathrm{~A} / \mathrm{G}$ polymorphisms in the two groups of healthy controls

\begin{tabular}{lllll}
\hline SNP & Group 1 $(N=168)$ & Group $2(N=307)$ & $P$ value & Total $(N=475)$ \\
\hline Allele & & & \\
A & $178(53.0)^{\mathrm{b}}$ & $347(56.5)$ & & $525(55.3)$ \\
$\mathrm{G}$ & $158(47.0)$ & $267(43.5)$ & 0.29 & $425(44.7)$
\end{tabular}

Phenotype

\begin{tabular}{|c|c|c|}
\hline $134(79.8)$ & 249 (81.1) & \\
\hline $124(73.8)$ & $209(68.1)$ & 0.53 \\
\hline
\end{tabular}

Genotype

\begin{tabular}{|c|c|c|c|c|}
\hline $\mathrm{AA}$ & $44(26.2)$ & 98 (31.9) & & $142(29.9)$ \\
\hline $\mathrm{AG}$ & $90(53.6)$ & $151(49.2)$ & & $241(50.7)$ \\
\hline GG & $34(20.2)$ & $58(18.9)$ & $0.43^{\mathrm{a}}$ & $92(19.4)$ \\
\hline
\end{tabular}

${ }^{\text {a }} P$ values for comparison of Group 1 and Group 2 .

b Percentages in parenthesis.

arthritic patient group (61.4 vs. $55.3 \%$ in controls; $P=0.012$, $\mathrm{OR}=1.28,95 \% \mathrm{CI}=1.06-1.56)$, and an identical, though non-significant, trend (61.8 vs. $55.3 \%$ in controls) was seen in the JIA patients. The number of homozygotes for the $+49 \mathrm{~A} /$ $\mathrm{G}^{*} \mathrm{~A}$ allele was increased, and that for the $* \mathrm{G}$ allele decreased in RA compared to the controls $(P=0.02, \mathrm{OR}=0.60, \mathrm{CI}=$ $0.39-0.92)$ as well as for the total arthritic patients group $(P=$ $0.01, \mathrm{OR}=0.58, \mathrm{CI}=0.39-0.88)$. Again, the JIA patients showed a similar trend $(P=0.121)$. Power was calculated to amount to $99.6 \%$ for RA patients and to $77.1 \%$ for JIA for detection of association of the $+49 \mathrm{~A} / \mathrm{G}$ SNP at a significance level of 0.05 with a modest OR of 2 .

The CT60 polymorphism was genotyped in the same set of patients and in the control population of Group 1. Similarly, the genotypes in the controls were in Hardy-Weinberg equilibrium $(P>0.5)$. The CT60 allele, phenotype and genotype frequencies did not differ significantly between RA and JIA patients and the controls (data not shown). Both the SNPs were in tight linkage disequilibrium $\left(D^{\prime}>0.8\right)$ in both the Group 1 controls as well as in the two patient populations.

The results of haplotype analysis are shown in Table 4. Markers were tested individually and subsequently as a pair. Of the 4 possible haplotypes, the $+49 \mathrm{~A} / \mathrm{G} * \mathrm{G}-\mathrm{CT} 60 * \mathrm{~A}$ haplotype was not seen in either of the patient groups while it was present in the control population $(4.2 \%$ in controls while $0 \%$ in both RA and JIA patients). The comparison of haplotypes using the EHPlus program showed a significant difference between the RA and JIA patients and the Group 1 controls $(P<0.00001$ in RA, $P=0.030$ in JIA and $P<0.00001$ in the combined arthritic patients group).

\section{Discussion}

Eight out of 12 available studies have reported association of CTLA-4 polymorphisms with RA (Table 1). Prior to this study, the $\mathrm{G}$ allele of the $+49 \mathrm{~A} / \mathrm{G}$ SNP was found to be associated with RA on seven occasions in five different ethnic populations (Cai et al., 2005; Lee et al., 2003; Vaidya et al., 2002; Yanagawa et al., 2000; Matsushita et al., 1999; Gonzalez-Escribano et al., 1999; Seidl et al., 1998). The 
Table 3

Allele, phenotype and genotype frequencies of the $+49 \mathrm{~A} / \mathrm{G}$ polymorphism in RA and JIA patients and healthy controls ${ }^{\mathrm{a}}$

\begin{tabular}{|c|c|c|c|c|c|c|c|}
\hline \multirow[t]{2}{*}{ SNP } & \multirow[t]{2}{*}{ Total controls $(N=475)$} & \multicolumn{2}{|l|}{ RA } & \multicolumn{2}{|l|}{ JIA } & \multicolumn{2}{|l|}{ Total patients } \\
\hline & & Counts $(N=289)$ & $P$ value & Counts $(N=72)$ & $P$ value & Counts $(N=361)$ & $P$ value \\
\hline \multicolumn{8}{|c|}{$+49 A / G$} \\
\hline \multicolumn{8}{|c|}{ Allele } \\
\hline A & $525(55.3)$ & $354(61.2)$ & & $89(61.8)$ & & $443(61.4)$ & \\
\hline G & $425(44.7)$ & $224(38.8)$ & 0.022 & $55(38.2)$ & 0.14 & $279(38.6)$ & 0.012 \\
\hline \multicolumn{8}{|c|}{ Phenotype } \\
\hline A & $383(80.6)$ & $249(86.2)$ & & $63(87.5)$ & & $312(86.4)$ & \\
\hline G & $333(70.1)$ & $184(63.7)$ & 0.19 & $46(63.9)$ & 0.40 & $230(63.7)$ & 0.15 \\
\hline \multicolumn{8}{|c|}{ Genotype } \\
\hline AA & $142(29.9)$ & $105(36.3)$ & & $26(36.1)$ & & $131(36.3)$ & \\
\hline $\mathrm{AG}$ & $241(50.7)$ & $144(49.8)$ & $0.2^{\mathrm{b}}$ & $37(51.4)$ & $0.52^{\mathrm{b}}$ & $181(50.1)$ & $0.187^{\mathrm{b}}$ \\
\hline \multirow[t]{2}{*}{ GG } & 92 (19.4) & $40(13.8)$ & $0.020^{\mathrm{c}}$ & $9(12.5)$ & $0.121^{\mathrm{c}}$ & 49 (13.6) & $0.010^{\mathrm{c}}$ \\
\hline & & & $0.064^{\mathrm{d}}$ & & $0.303^{\mathrm{d}}$ & & $0.036^{\mathrm{d}}$ \\
\hline
\end{tabular}

\footnotetext{
${ }^{\text {a }}$ Percentages in parenthesis.

b $P$ value for comparison of AG genotype vs. AA homozygotes.

c $P$ value for comparison of GG homozygotes vs. AA homozygotes.

${ }^{\mathrm{d}} P$ value for comparison of the 3 genotypes.
}

present study done in RA and JIA patients from a homogenous Northern Irish population reveals a unique, though relatively weak, association of the +49 A allele that has not been shown before in RA and JIA patients of other ethnic groups. To validate that the association of the +49 A allele with RA and JIA was not due to any peculiarities specific to the control group of healthy blood donors used, we genotyped a second control population consisting of healthy children of Northern Irish origin. This would ascertain that the control populations reflect the true genotypic distribution of this polymorphism. Interestingly, allele distribution in the second control population was not statistically different from that in the first control group. Our data therefore prove that the A allele of the CTLA-4 +49 A/G SNP may de facto be associated with RA, and specifically, that GG homozygotes are under-represented and AA homozygotes over-represented in Northern Irish RA patients and total arthritic patients. This distortion in the distribution of the homozygotes in the RA patients and total arthritic patients was statistically significant, but did not reach statistical significance in the JIA patients even though there was $77.1 \%$ power to detect an association at the 0.05 level of significance in the JIA patients.

Table 4

Haplotype analysis of the $+49 \mathrm{~A} / \mathrm{G}$ SNP and CT60 SNPs in the CTLA- 4 gene in healthy controls, RA and JIA patients of Northern Irish descent

\begin{tabular}{lclc}
\hline Haplotype & $\begin{array}{l}\text { Controls } \\
(2 N=336)\end{array}$ & $\begin{array}{l}\text { RA } \\
(2 N=578)^{\mathrm{a}}\end{array}$ & $\begin{array}{l}\text { JIA } \\
(2 N=144)^{\mathrm{b}, \mathrm{c}}\end{array}$ \\
\hline$+49 \mathrm{~A} / \mathrm{G}^{*} \mathrm{~A}-\mathrm{CT} 60 * \mathrm{~A}$ & $131(38.9)^{\mathrm{d}}$ & $234(40.5)$ & $63(43.8)$ \\
$+49 \mathrm{~A} / \mathrm{G}^{*} \mathrm{~A}-\mathrm{CT} 60 * \mathrm{G}$ & $47(14.1)$ & $120(20.8)$ & $26(18.1)$ \\
$+49 \mathrm{~A} / \mathrm{G}^{*} \mathrm{G}-\mathrm{CT} 60 * \mathrm{~A}$ & $14(4.2)$ & 0 & 0 \\
$+49 \mathrm{~A} / \mathrm{G}^{*} \mathrm{G}-\mathrm{CT} 60 * \mathrm{G}$ & $144(42.8)$ & $224(38.7)$ & $55(38.2)$ \\
\hline
\end{tabular}

${ }^{\text {a }} P$ value $<0.00001$ obtained from EHPlus for the comparison of haplotypes of RA patients vs. controls.

${ }^{\mathrm{b}} P$ value $=0.030$ obtained from EHPlus for the comparison of haplotypes of JIA patients vs. controls.

${ }^{\mathrm{c}} P$ value $<0.00001$ obtained from EHPlus for the comparison of haplotypes of combined arthritic patients vs. controls.

${ }^{\mathrm{d}}$ Values in numbers (\%). Frequency obtained using Arlequin software.
Association of the +49 A allele with inflammatory disorders has been shown also in independent studies involving Swedish (Torinsson Naluai et al., 2000) and French (Djilali-Saiah et al., 1998) patients with celiac disease, as well as in a small group of MS patients (Waliszewska et al., 2002). An explanation could reside in the notion of the +49 A/G SNP being in linkage disequilibrium with an as yet to be uncovered functional polymorphism. Due to factors specific to certain populations including restricted immigration over time due to geographical isolation, founder effects, population history including recombination and natural selection events, then, the $+49 \mathrm{~A} / \mathrm{G}^{*} \mathrm{~A}$ allele may have become 'linked' to the actual diseasepredisposing SNP, thus materializing as a unique marker for disease predisposition in autoimmune disorders in this population. Interaction of marker allele frequencies and disease heterogeneity could also play a role in explaining why an association to the $\mathrm{G}$ allele has not been replicated in our, and neither in other (Torinsson Naluai et al., 2000; Djilali-Saiah et al., 1998; Waliszewska et al., 2002), patient groups.

Ueda et al. (2003) recently identified the CT60 polymorphism as being the one in the CTLA4 region most strongly associated with autoimmune disease, and showed the $+49 \mathrm{~A} /$ G*G-CT $60 * \mathrm{G}$ haplotype to be associated with susceptibility to autoimmunity. We did not replicate these findings (Ueda et al., 2003). However, we demonstrated that $+49 \mathrm{~A} / \mathrm{G}-\mathrm{CT} 60$ haplotype distribution is significantly different between RA or JIA patients, and controls, reinforcing a role for CTLA-4 in autoimmunity.

In recent years, the therapeutic potential of CTLA- 4 has been investigated in both animal models and in clinical trials in patients with rheumatoid arthritis. A bio-drug composed of human CTLA-4 fused to the constant region of IgG1 has been used and found to be effective in preventing or treating disease by blocking T cell activation (Takahashi et al., 2005; Kremer et al., 2003; Moreland et al., 2002; Quattrocchi et al., 2000). With a future pharmacogenetic application in mind, our study may raise a set of challenges regarding the feasibility of tailoring CTLA-4-based drugs to patients on the basis of their genetic 
CTLA4 profiles. As already mentioned earlier in the discussion, it is common to see the $\mathrm{G}$ allele of the $+49 \mathrm{~A} / \mathrm{G}$ SNP to be associated with autoimmune diseases. However, in our population, it was the A allele that was found to be associated with RA and JIA. Thus, it would be of relevance to investigate if this, or any other polymorphism(s), is involved in the way the patients respond to such drugs.

\section{Acknowledgments}

This study was supported with a grant from the Northern Ireland HPSS R\&D Office (RRG 11.5). We express our gratitude to all the RA and JIA patients for their willingness to cooperate in the present study.

\section{References}

Arnett, F.C., Edworthy, S.M., Bloch, D.A., McShane, D.J., Fries, J.F., Cooper, N.S., Healey, L.A., Kaplan, S.R., Liang, M.H., Luthra, H.S., et al., 1988. The American Rheumatism Association 1987 revised criteria for the classification of rheumatoid arthritis. Arthritis Rheum. 31, 315-324.

Barton, A., Myerscough, A., John, S., Gonzalez-Gay, M., Ollier, W., Worthington, J., 2000. A single nucleotide polymorphism in exon 1 of cytotoxic T-lymphocyte-associated-4 (CTLA-4) is not associated with rheumatoid arthritis. Rheumatology 39, 63-66.

Cai, L., Zhang, D., Shi, Y., Oaks, M.K., Chan, L., Jin, J., Qian, J., Du, F., Li, N., Han, X., Ren, D.M., 2005. Association of the CTLA-4 gene with rheumatoid arthritis in Chinese Han population. Eur. J. Hum. Genet. 13, $823-828$.

Dariavach, P., Mattéi, M.G., Golstein, P., Lefranc, M.P., 1988. Human Ig superfamily CTLA-4 gene: chromosomal localization and identity of protein sequence between murine and human CTLA 4 cytoplasmic domains. Eur. J. Immunol. 18, 1901-1905.

Djilali-Saiah, I., Schmitz, J., Harfouch-Hammoud, E., Mougenot, J.-F., Bach, J.-F., Caillat-Zucman, S., 1998. CTLA-4 gene polymorphism is associated with predisposition to coeliac disease. Gut 43, 187-189.

Eyre, S., Barton, A., Shephard, N., Hinks, A., Brintnell, W., MacKay, K., Silman, A., Ollier, W., Wordsworth, P., John, S., Worthington, J., 2004. Investigation of susceptibility loci identified in the UK rheumatoid arthritis whole-genome scan in a further series of 217 UK affected sibling pairs. Arthritis Rheum. 50, 729-735.

Feldmann, M., Brennan, F., Maini, R., 1996. Rheumatoid arthritis. Cell 85, $307-310$.

Forre, O., Vinje, O., Flate, B., et al., 1997. CTLA-4 polymorphism and susceptibility to juvenile rheumatoid arthritis (JRA). Arthritis Rheum 40 (suppl: Abstract no. 1264).

Glass, D.N., Giannini, E.H., 1999. Juvenile rheumatoid arthritis as a complex genetic trait. Arthritis Rheum. 42, 2261-2268.

Gonzalez-Escribano, M.F., Rodriguez, R., Valenzuela, A., Garcia, A., GarciaLozano, J.R., Nunez-Roldan, A., 1999. CTLA4 polymorphisms in Spanish patients with rheumatoid arthritis. Tissue Antigens 53, 296-300.

Gregersen, P.K., 2003. Teasing apart the complex genetics of human autoimmunity: lessons from rheumatoid arthritis. Clin. Immunol. 10, 1-9.

Grom, A.A., Giannini, E.H., Glass, D.N., 1994. Juvenile rheumatoid arthritis and the trimolecular complex (HLA, T cell receptor and antigen). Differences from rheumatoid arthritis. Arthritis Rheum. 37, 601-607.

Hadj Kacem, H., Kaddour, N., Adyel, F.-Z., Bahloul, Z., Ayadi, H., 2001. HLA-DQB1 CAR1/CAR2, TNFa IR2/IR4 and CTLA-4 polymorphisms in Tunisian patients with rheumatoid arthritis and Sjögren's syndrome. Rheumatology 40, 1370-1374.

Jawaheer, D., Seldin, M.F., Amos, C.I., Chen, W.V., Shigeta, R., Monteiro, J., Kern, M., Criswell, L.A., Albani, S., Nelson, J.L., Clegg, D.O., Pope, R., Schroeder Jr., H.W., Bridges Jr., S.L., Pisetsky, D.S., Ward, R., Kastner, D.L., Wilder, R.L., Pincus, T., Callahan, L.F., Flemming, D., Wener, M.H., Gregersen, P.K., 2001. A genomewide screen in multiplex rheumatoid arthritis families suggests genetic overlap with other autoimmune diseases. Am. J. Hum. Genet. 68, 927-936.

Kremer, J.M., Westhovens, R., Loen, M., Di Giorgio, E., Alten, R., Steinfel, S., Russell, A., Dougados, M., Emery, P., Nuamah, I.F., et al., 2003. Treatment of rheumatoid arthritis by selective inhibition of T-cell activation with fusion protein CTLA4Ig. N. Engl. J. Med. 349, 1907-1915.

Lee, Y.H., Choi, S.J., Ji, J.D., Song, G.G., 2002. No association of polymorphisms of the CTLA-4 exon $1(+49)$ and promoter $(-318)$ genes with rheumatoid arthritis in the Korean population. Scand. J. Rheumatol. $31,266-270$

Lee, C.-S., Lee, Y.-J., Liu, H.-F., Su, C.-H., Chang, S.-C., Wang, B.-R., Chen, T.-L., Liu, T.-L., 2003. Association of CTLA4 gene A-G polymorphism with rheumatoid arthritis in Chinese. Clin. Rheumatol. $22,221-224$

Matsushita, M., Tsuchiya, N., Shiota, M., Komata, T., Matsuta, K., Zama, K., Oka, T., Juji, T., Yamane, A., Tokunaga, K., 1999. Lack of a strong association of CTLA-4 exon 1 polymorphism with susceptibility to rheumatoid arthritis and systemic lupus erythematosus in Japanese: an association study using a novel variation screening method. Tissue Antigens 54, 578-584.

McCormack, R.M., Maxwell, A.P., Carson, D., Patterson, C.C., Bingham, A., Savage, D.A., 2001. Possible association between CTLA4 DNA polymorphisms and early onset type 1 diabetes in a UK population. Genes Immun. 2, 233-235.

Milicic, A., Brown, M.A., Wordsworth, B.P., 2001. Polymorphism in codon 17 of the CTLA-4 gene $(+49 \mathrm{~A} / \mathrm{G})$ is not associated with susceptibility to rheumatoid arthritis in British Caucasians. Tissue Antigen 58, 50-54.

Moreland, L.W., Alten, R., Van den Bosch, F., Appelboom, T., Leon, M., Emery, P., Cohen, S., Luggen, M., Shery, W., Muamah, I., Becker, J.C., 2002. Costimulatory blockade in patients with rheumatoid arthritis: a pilot, dose-finding, double-blind, placebo-controlled clinical trial evaluating CTLA-4Ig and LEA29Y eighty-five days after the first infusion. Arthritis Rheum. 46, 1470-1479.

Moroldo, M.B., Chaudhari, M., Shear, E., Thompson, S.D., Glass, D.N., Giannini, E.H., 2004. Juvenile rheumatoid arthritis affected sibpairs: extent of clinical phenotype concordance. Arthritis Rheum. 50, 1928-1934.

Ollier, W.E.R., 2004. Cytokine genes and disease susceptibility. Cytokine 28, $174-178$

Oosterwegel, M.A., Greenwald, R.J., Mandelbrot, D.A., Lorsbach, R.B., Sharpe, A.H., 1999. CTLA-4 and T cell activation. Curr. Opin. Immunol. $11,294-300$.

Orozco, G., Torres, B., Núñez-Roldán, A., González-Escribano, M.F., Martin, J., 2004. Cytotoxic T-lymphocyte antigen-4-CT60 polymorphism in rheumatoid arthritis. Tissue Antigen 64, 667-670.

Osorio, Y., Fortea, J., Bukulmez, H., Petit-Teixeira, E., Michou, L., Pierlot, C., Cailleau-Moindrault, S., Lemaire, I., Lasbleiz, S., Alibert, O., Quillet, P., Bardin, T., Prum, B., Olson, J.M., Cornelis, F., 2004. Dense genome-wide linkage analysis of rheumatoid arthritis, including covariates. Arthritis Rheum. 50, 2757-2765.

Petty, R.E., Southwood, T.R., Baum, J., Bhettay, E., Glass, D.N., Manners, P., Maldonado-Cocco, J., Suarez-Almazor, M., Orozco-Alcala, J., Prieur, A.M., 1998. Revision of the proposed classification criteria for juvenile idiopathic arthritis: Durban, 1997. J. Rheumatol. 25, 1991-1994.

Power, D., Codd, M., Ivers, L., Sant, S., Barry, M., 1999. Prevalence of rheumatoid arthritis in Dublin, Ireland: a population based survey. Ir. J. Med. Sci. 168, 197-200.

Quattrocchi, E., Dallman, M.J., Feldmann, M., 2000. Adenovirus-mediated gene transfer of CTLA-4Ig fusion protein in the suppression of experimental autoimmune arthritis. Arthritis Rheum. 43, 1688-1697.

Risch, N., 1987. Assessing the role of HLA-linked and unlinked determinations of disease. Am. J. Hum. Genet. 40, 1.

Rodríguez, M.R., Núñez-Roldán, A., Aguilar, F., Valenzuela, A., García, A., González-Escribano, M.F., 2002. Association of the CTLA4 3' untranslated region polymorphism with the susceptibility to rheumatoid arthritis. Hum. Immunol. 63, 76-81.

Seidl, C., Donner, H., Fischer, B., Usadel, K.H., Seifried, E., Kaltwasser, J.P., Badenhoop, K., 1998. CTLA4 codon 17 dimorphism in patients with rheumatoid arthritis. Tissue Antigens 51, 62-66. 
Suppiah, V., Alloza, I., Heggarty, S., Goris, A., Dubois, B., Carton, H., Vandenbroeck, K., 2005. The CTLA4 $+49 \mathrm{~A} / \mathrm{G}^{*} \mathrm{G}-\mathrm{CT} 60 * \mathrm{G}$ haplotype is associated with susceptibility to multiple sclerosis in Flanders. J. Neuroimmunol. 164, 148-153.

Takahashi, S., Kataoka, H., Hara, S., Yokosuka, T., Takase, K., Yamasaki, S., Kobayashi, W., Saito, Y., Saito, T., 2005. In vivo overexpression of CTLA4 suppresses lymphoproliferative diseases and thymic negative selection. Eur. J. Immunol. 35, 399-407.

Thompson, S.D., Moroldo, M.B., Guyer, L., Ryan, M., Tombragel, E.M., Shear, E.S., Prahalad, S., Sudman, M., Keddache, M.A., Brown, W.M., et al., 2004. A genome-wide scan for juvenile rheumatoid arthritis in affected sibpair families provides evidence of linkage. Arthritis Rheum. 50, $2920-2930$.

Tivol, E.A., Borriello, F., Schweitzer, A.N., Lynch, W.P., Bluestone, J.A., Sharpe, A.H., 1995. Loss of CTLA-4 leads to massive lymphoproliferation and fatal multiorgan tissue destruction, revealing a critical negative regulatory role of CTLA-4. Immunity 3, 541-547.

Torinsson Naluai, Å., Nilsson, S., Samuelsson, L., Gudjonsdottir, A.H., Ascher, H., Ek, J., Hallberg, B., Kristiansson, B., Martinsson, T., Nerman, O., Sollid, L.M., Wahlstrom, J., 2000. The CTLA4/CD28 gene region on chromosome $2 \mathrm{q} 33$ confers susceptibility to celiac disease in a way possibly distinct from that of type 1 diabetes and other chronic inflammatory disorders. Tissue Antigens 56, 350-355.
Ueda, H., Howson, J.M., Esposito, L., Heward, J., Snook, H., Chamberlain, G., Rainbow, D.B., Hunter, K.M., Smith, A.N., Di Genova, G., Herr, M.H., Dahlman, I., Payne, F., Smyth, D., Lowe, C., Twells, R.C., Howlett, S., Healy, B., Nutland, S., Rance, H.E., Everett, V., Smink, L.J., Lam, A.C., Cordell, H.J., Walker, N.M., Bordin, C., Hulme, J., Motzo, C., Cucca, F., et al., 2003. Association of the T cell regulatory gene CTLA-4 with susceptibility to autoimmune disease. Nature 423, 506-511.

Vaidya, B., Pearce, S.H.S., Charlton, S., Marshall, N., Rowan, A.D., Griffiths, I.D., Kendall-Taylor, P., Cawston, T.E., Young-Min, S., 2002. An association between the CTLA4 exon 1 polymorphism and early rheumatoid arthritis with autoimmune endocrinopathies. Rheumatology 41, 180-183.

Waliszewska, A., Buckle, G.J., Hafler, D., 2002. CTLA-4 polymorphisms in patients with multiple sclerosis phenotype. Focis, 397 (Abstract).

Waterhouse, P., Penninger, J.M., Timms, E., Wakeham, A., Shahinian, A., Lee, K.P., Thompson, C.B., Griesser, H., Mak, T.W., 1995. Lymphoproliferative disorders with early lethality in mice deficient in Ctla-4. Science 270,985-988.

Wood, P.H.N., 1978. Nomenclature and classification of arthritis in children. In: Munthe, E. (Ed.), The Care of Rheumatic Children. Basel: Eular, p. 47.

Yanagawa, T., Gomi, K., Nakao, E.I., Inada, S., 2000. CTLA-4 gene polymorphism in Japanese patients with rheumatoid arthritis. J. Rheumatol. 27, 2740-2742.

Zhao, J.H., Sham, P.C., 2002. Faster allelic association analysis using unrelated subjects. Hum. Hered. 53, 36-41. 